University of Nebraska - Lincoln

DigitalCommons@University of Nebraska - Lincoln

USDA National Wildlife Research Center - Staff Publications
U.S. Department of Agriculture: Animal and Plant Health Inspection Service

2010

\title{
Cold weather and the potential range of invasive Burmese pythons
}

\author{
Michael L. Avery \\ USDA, Animal and Plant Health Inspection Service, Wildlife Services, National Wildlife Research Center, \\ michael.l.avery@aphis.usda.gov \\ Richard M. Engeman \\ USDA-APHIS-Wildlife Services, s_r100@yahoo.com \\ Kandy L. Keacher \\ USDA, Animal and Plant Health Inspection Service, Wildlife Services, National Wildlife Research Center \\ John S. Humphrey \\ USDA/APHIS/WS National Wildlife Research Center, John.S.Humphrey@aphis.usda.gov \\ William E. Bruce \\ USDA, Animal and Plant Health Inspection Service, Wildlife Services, National Wildlife Research Center
}

See next page for additional authors

Follow this and additional works at: https://digitalcommons.unl.edu/icwdm_usdanwrc

Part of the Environmental Sciences Commons

Avery, Michael L.; Engeman, Richard M.; Keacher, Kandy L.; Humphrey, John S.; Bruce, William E.; Mathies, Tom C.; and Mauldin, Richard E., "Cold weather and the potential range of invasive Burmese pythons" (2010). USDA National Wildlife Research Center - Staff Publications. 869.

https://digitalcommons.unl.edu/icwdm_usdanwrc/869

This Article is brought to you for free and open access by the U.S. Department of Agriculture: Animal and Plant Health Inspection Service at DigitalCommons@University of Nebraska - Lincoln. It has been accepted for inclusion in USDA National Wildlife Research Center - Staff Publications by an authorized administrator of DigitalCommons@University of Nebraska - Lincoln. 


\section{Authors}

Michael L. Avery, Richard M. Engeman, Kandy L. Keacher, John S. Humphrey, William E. Bruce, Tom C. Mathies, and Richard E. Mauldin 


\title{
Cold weather and the potential range of invasive Burmese pythons
}

\author{
Michael L. Avery • Richard M. Engeman • \\ Kandy L. Keacher • John S. Humphrey • \\ William E. Bruce · Tom C. Mathies • Richard E. Mauldin
}

Received: 19 February 2010/ Accepted: 6 April 2010

(C) US Government 2010

\begin{abstract}
The Burmese python (Python molurus bivittatus) is established in Everglades National Park and neighboring areas in south Florida. Beyond its substantial ecological impacts to native fauna in south Florida, concerns have been raised as to its potential to occupy other parts of the USA, even as far north as Washington, DC. During a recent period of cold weather, seven of nine captive Burmese pythons held in outdoor pens at our facility in northcentral Florida died, or would have died absent our intervention. This cold-induced mortality occurred despite the presence of refugia with heat sources. Our findings cast doubt on the ability of free-ranging Burmese pythons to establish and persist beyond the subtropical environment of south Florida.
\end{abstract}

Keywords Burmese python · Florida . Geographic range $\cdot$ Invasive species ·

Python molurus bivittatus

M. L. Avery $(\bowtie) \cdot$ K. L. Keacher · J. S. Humphrey · W. E. Bruce

USDA, Animal and Plant Health Inspection Service, Wildlife Services, National Wildlife Research Center, Florida Field Station, 2820 East University Avenue, Gainesville, FL, USA

e-mail: michael.1.avery@aphis.usda.gov

R. M. Engeman - T. C. Mathies - R. E. Mauldin USDA, Animal and Plant Health Inspection Service, Wildlife Services, National Wildlife Research Center, 4101 LaPorte Avenue, Fort Collins, CO, USA

\section{Introduction}

The invasive Burmese python has been entrenched in south Florida for over a quarter-century (Meshaka et al. 2000). This taxon, long recognized as Python molurus bivittatus, has recently been reassessed as Python bivittatus bivittatus (Jacobs et al. 2009). The species' invasion pathway in south Florida has been largely attributed to (illegal) pet releases, although the highly destructive Hurricane Andrew in 1992 may also have released many from captive breeding and holding facilities (Snow et al. 2007; Bilger 2009). The extent of the species' potential range beyond south Florida has been the subject of considerable controversy (Snow et al. 2007; Pyron et al. 2008; Rodda et al. 2009). A climate matching approach using mean monthly climate information from within the native range of the Burmese python and the closely related Indian python (Python molurus molurus) produced potential range projections north to Delaware and southern Maryland and west to California (Rodda et al. 2009). Ecological niche modeling using Burmese python native range information and incorporating temperature extremes, not only mean values, generated much narrower projections with only extreme south Texas added to its current introduced range (Pyron et al. 2008). While these divergent projections for the potential range of the Burmese python have led to spirited discussion, little empirical information is available to indicate whether the species might indefinitely survive, let alone establish sustained breeding 
populations beyond south Florida. Here, we present evidence that, even with refugia and heat sources, adult Burmese pythons are unable to survive cold weather events in the central Florida peninsula, $400 \mathrm{~km}$ north of their currently known introduced range.

\section{Methods}

During February-March 2008, 3 female and 6 male adult Burmese pythons were wild-caught in or around Everglades National Park and transported to Gainesville, FL $\left(29^{\circ} 39^{\prime} 11^{\prime \prime} \mathrm{N}, 82^{\circ} 17^{\prime} 15^{\prime \prime} \mathrm{W}\right)$. At the USDA/ APHIS/WS/National Wildlife Research Center field station, each python was individually housed outdoors in a pen $3.0 \mathrm{~m}$ long $\times 1.5 \mathrm{~m}$ wide $\times 1.8 \mathrm{~m}$ high. The pens were aluminum frame construction enclosed with plastic-coated wire.

In each pen, we provided a plywood hide box $(61 \times 61 \times 29 \mathrm{~cm})$ covered in $5 \mathrm{~cm}$ thick polystyrene insulation board and wrapped in medium gauge black plastic. Access to the box was through a $15 \times 15 \mathrm{~cm}$ opening covered by plastic strips to create a "curtain" type entrance. The floor of the box was a $1.2 \mathrm{~cm}$ thick polystyrene insulation board to help retain heat and to reduce moisture from the ground. On top of the floor board, we installed a heat mat $(45.7 \times 45.7 \mathrm{~cm}$; Kane Manufacturing Company, Des Moines, IA) set at $27^{\circ} \mathrm{C}$ and controlled with an electronic thermostat (R-Zilla ${ }^{\circledR}$ Central Garden \& Pet, Franklin, WI). We added a folded blanket to give the snake additional options for controlling its heat exposure. Each pen also included a plastic water pool (1 m diameter, $20 \mathrm{~cm}$ deep) and large branches for basking. The individual pens were all situated within a netted 0.2 ha flight pen secured against python escape.

For each python pen, the heat mat surface temperature and the outside temperature were recorded hourly from 1 November 2009 through 12 January 2010 (Oakton Temp Log, Oakton Instruments, Vernon Hills, IL). During 14 January-8 February, we added temperature probes to 2 hide boxes to record hourly air temperatures 12 and $25 \mathrm{~cm}$ above the heat mat. These additional temperature data were used to establish the probable relationship between ambient conditions and air temperatures inside the hide boxes during 3-12 January when we experienced particularly cold weather.
The captive pythons were test subjects in behavioral studies of reproductive behavior, responses to chemical cues, and responses to capture technologies and strategies. They had lived outdoors throughout the previous winter and they remained there during a regional cold weather spell in December 2009 and January 2010 which permitted opportunistic observations of cold weather behavior and survival of the snakes.

\section{Results}

During the 2008/2009 winter, the ambient temperature at our study site was below freezing on 15 nights. In January 2010 alone, subfreezing temperatures occurred on 10 nights. Furthermore, from midnight on 2 January to noon on 12 January, hourly ambient temperatures were at or below freezing $47 \%$ of the time. During this 10.5-day period, $55-61 \%$ of the time the calculated temperatures inside the hide boxes of the pythons were $\leq 10^{\circ} \mathrm{C}$, a threshold below which pythons increasingly are at risk of dying from exposure (Barker 2008).

During the cold spell, 3 of the 9 pythons were found dead. Two others developed infections and were euthanized after consultation with and at the recommendation of our attending veterinarian. Two snakes exhibited clinical signs (wheezing, nasal discharge) of respiratory distress, most likely fatal had we not intervened (E. R. Jacobson, University of Florida, Gainesville, FL, personal comment). In keeping with our responsibility under animal care and use guidelines, we moved these snakes indoors to recover. The final two pythons (both males, 3.4 and $9.0 \mathrm{~kg}$, respectively) showed no ill effects and remained outdoors. Thus, including the 2 snakes with overt respiratory problems, we ascribe mortality from cold weather effects to 7 of the 9 pythons.

Pythons were not subject to round the clock surveillance, but during routine maintenance we observed behavior seemingly contradictory to a cold weather survival instinct. The first instance occurred on 16 November 2009 when the second largest male $(9.05 \mathrm{~kg})$ was outside in $8^{\circ} \mathrm{C}$ air temperature. This snake was one of the two euthanized later due to infections. The largest snake $(18.45 \mathrm{~kg})$ was atop her hide box at $14: 08$ on 5 January 2010 when the air temperature was $10^{\circ} \mathrm{C}$. The next day this same snake 
was again on top of her hide box at 11:10 with air temperatures from $-3.3^{\circ} \mathrm{C}$ at $08: 30$ to $7.3^{\circ} \mathrm{C}$ at $11: 30$. She was again on top of her hide box at 11:20 on 11 January 2010 with the air temperature ranging from $-5.7^{\circ} \mathrm{C}$ at $8: 30$ to $9^{\circ} \mathrm{C}$ at $11: 30$. At the same time, the temperature on the heat pad inside the hide box was $26.7^{\circ} \mathrm{C}$. At 1730 , when the outside temperature was $5.0^{\circ} \mathrm{C}$, we brought this snake indoors in an attempt (unsuccessful) to insure her health. Shortly afterwards, we noticed the third smallest male $(8.11 \mathrm{~kg})$ outside its hide box when the outdoor temperature was $3.25^{\circ} \mathrm{C}$, and we moved it inside to recover from apparent respiratory distress.

\section{Discussion}

We recognize that our pythons are not perfectly representative of free-living pythons. But, if wild pythons had existed in north-central Florida during the 2009-2010 winter, we contend their survival rate would likely not have matched that of the captive pythons. Our animals approached winter well-fed, with the benefit of daily attention from trained animal care professionals, and with free access to a heated refuge, advantages not guaranteed for pythons in the wild. Thus, our results may well provide insight to the upper limits for survival probability of adult Burmese pythons in north central Florida during a prolonged period of cold weather.

Our pythons were wild-caught in the Everglades National Park region (ca $400 \mathrm{~km}$ south of Gainesville) and subsequently maintained in ambient conditions in pens large enough to give the snakes options for refuge, thermal regulation, and exposure. Barker (2008) observed that captive tropical constrictors, including Burmese pythons, did not exhibit behaviors for avoiding lethally cold temperatures. The tropical pythons appeared unable to recognize potentially lethal cold, with the snakes' urge to explore rather than shelter placing them at risk. Barker (2008) did not find the same lack of survival response relative to cold weather extremes in subtropical species, which have evolved in climates with occasional cold spells.

Recent genetic results showed little differentiation among Burmese pythons captured in south Florida (Collins et al. 2008). As with many invasive species, the founding population sources are probably multiple and may never be definitively known. Nevertheless, a potentially significant consequence of the lack of genetic variation among the south Florida pythons may be reduced behavioral and ecological flexibility, with a resultant inability to adapt to significant changes in climatic conditions. Moreover, Aubret and Shine (2010) concluded that snakes' thermoregulatory tactics are based more in the conditions of their raising than their current thermoregulatory opportunities, thus making year-toyear temperature variation their major thermoregulatory challenge for survival.

Our results, while not definitive, support the view that climatic variables affecting the extent of a species' range are likely defined by their extremes in magnitude and duration, rather than by average values. Our empirical observations on the impacts of the cold weather event are consistent with results from recent niche modeling efforts (Pyron et al. 2008) and cast doubt that Burmese pythons can become established and persist beyond the southern portion of the Florida peninsula.

Acknowledgments We appreciate the efforts of R. W. Snow in acquiring the pythons for us. We thank E. Fetzer and $\mathrm{K}$. Maciejewski for assistance in caring for the snakes.

\section{References}

Aubret F, Shine R (2010) Thermal plasticity in young snakes: how will climate change affect the thermoregulatory tactics of ectotherms? J Exp Biol 213:242-248

Barker DG (2008) Will they come in out of the cold? Observations of large constrictors in cool and cold conditions. Bull Chicago Herpetol Soc 43:93-97

Bilger B (2009) Swamp things. New Yorker 85:80-89

Collins TM, Freeman B, Snow S (2008) Final report: genetic characterization of populations of the nonindigenous Burmese python in Everglades National Park. Final report for the South Florida Water Management District. Department of Biological Sciences, Florida International University, Miami, Florida

Jacobs HJ, Auliya M, Böhme W (2009) Zur taxonomie des dunklen tigerpythons, Python molurus bivittatus Kuhl, 1820, speziell der population von Sulawesi. Sauria 31:5-16

Meshaka WE Jr, Loftus WF, Steiner T (2000) The herpetofauna of Everglades National Park. Florida Sci 63:84-103

Pyron RA, Burbrink FT, Guiher TJ (2008) Claims of potential expansion throughout the U.S. by invasive python species are contradicted by ecological niche models. PLoS ONE 3:e2931

Rodda GH, Jarnevich CS, Reed RN (2009) What parts of the US mainland are climatically suitable for invasive alien 
M. L. Avery et al.

pythons spreading from Everglades National Park? Biol Inv 11:241-252

Snow RW, Krysko KL, Enge KM, Oberhofer L, WalkerBradley A, Wilkins L (2007) Introduced populations of
Boa constrictor (Boidae) and Python molurus bivittatus (Pythonidae) in southern Florida. In: Henderson RW, Powell R (eds) The biology of boas and pythons. Eagle Mountain Publishing, Eagle Mountain, UT, pp 416-438 